\title{
Morphology and in situ sedimentation of the cysts of a planktonic oligotrich ciliate, Strombidium capitatum
}

\author{
Young-Ok Kim ${ }^{1, *}$, Sungyong $\mathrm{Ha}^{1}$, Akira Taniguchi ${ }^{2,3}$ \\ ${ }^{1}$ Korea Ocean Research \& Development Institute, Geoje 656-830, Republic of Korea \\ ${ }^{2}$ School of Agriculture, Tohoku University, Sendai, Miyagi 981-8555, Japan \\ ${ }^{3}$ Present address: Tokyo University of Agriculture Okhotsk, Abashiri, Hokkaido 099-2493, Japan
}

\begin{abstract}
The cysts of the oligotrich ciliate Strombidium capitatum isolated from the natural sediments in Onagawa Bay, Japan, and Masan Bay, Korea, were described and incubated to produce vegetative cells. The vegetative cells that were obtained were observed after protargol staining and with a scanning microscope and then described. The cysts of $S$. capitatum were spherical with a papula and spiny surface. Their size varied from 55 to $62 \mu \mathrm{m}$ in total length and from 45 to $55 \mu \mathrm{m}$ in width. Seasonal changes in the vegetative population and in sedimentation of the newly formed cysts were investigated in situ in both bays. Planktonic vegetative cells peaked in autumn (December) in Onagawa Bay and in spring (April) in Masan Bay, when water temperature was ca. $15^{\circ} \mathrm{C}$. In contrast, the cells were not detected in either bay in summer. Mass encystment occurred in March in Onagawa Bay and in November in Masan Bay without coincidence with the peaks in vegetative populations at either locality. These results indicate that $S$. capitatum is adapted to low and moderate temperatures and aestivates during warm summer.
\end{abstract}

KEY WORDS: Strombidium capitatum • Cyst morphology · Cyst sedimentation · Oligotrich ciliate · Excystment $\cdot$ Onagawa Bay $\cdot$ Masan Bay

\section{INTRODUCTION}

Ciliate populations occur suddenly in great abundance and disappear rapidly from the planktonic community in the water column. Such opportunistic occurrence is said to depend mainly on food availability (Müller et al. 2002, Kim et al. 2007). Abrupt disappearance of the ciliates could be linked to formation and sinking of cysts, but few investigations have focused on encystment as a part of planktonic population dynamics in the water column.

Only a few species of oligotrich ciliates have been examined for their cysts due to the difficulty in species identification and sorting out from natural sediments. Occurrences of cysts were recorded for 2 marine species, Strombidium conicum and Cyrtostrombidium boreale, in the natural sediments in Onagawa Bay, Japan (Kim \& Taniguchi 1995, 1997, Kim et al. 2002), and for 2 freshwater species, Limostrombidium viride and Pelagostrombidium fallax, in a subalpine lake in Germany (Müller \& Wünsch 1999). Encystment of strombidiid ciliates was observed in an Austrian alpine lake (Müller et al. 2002). Many detailed studies on cysts have been carried out for the freshwater ciliate Meseres corlissi for its wall structure and ex- and encystment processes (Foissner 2005, Foissner et al. 2005, 2006, Müller 2007). Nevertheless, knowledge about the cysts of oligotrich ciliates is still limited, particularly in the marine environment.

Strombidium capitatum is a common and dominant oligotrich in temperate marine coastal waters (Rassoulzadegan 1977, Kim 1995, Kim et al. 2007), and it is known as a mixotrophic species retaining functional plastids (Laval-Peuto \& Rassoulzadegan 1988, Stoecker et al. 1988/1989). However, its cysts have not yet been described. 
We isolated a type of oligotrich cyst possessing a papula from marine sediments in Korean and Japanese embayments facing respectively to the East/Japan Sea and the northwest Pacific, which was identified to be Strombidium capitatum on the basis of the excysted vegetative cells. To illustrate and compare population dynamics in 2 localities, we observed the seasonality of vegetative and cyst populations in the 2 embayments.

\section{MATERIALS AND METHODS}

Planktonic population and sinking cysts in the water column. Abundance of Strombidium capitatum in the water column was investigated monthly from July 1993 to July 1994 at a station in Onagawa Bay, Japan, and from October 2005 to November 2006 at a station in Masan Bay, Korea (Fig. 1). Average water depths at the stations were 17 and $10 \mathrm{~m}$, respectively. Water samples were collected using a Van Dorn bottle at $0.5,10$, and $15 \mathrm{~m}$ (adding $15 \mathrm{~m}$ in 1994) in Onagawa Bay and at $0.5 \mathrm{~m}$ in Masan Bay. The samples were fixed immediately in Bouin's solution at a final concentration of $5 \%$ and then treated with the quantitative protargol staining (QPS) method (Montagnes \& Lynn 1987). Water temperature and salinity were recorded using a digital bathythermograph. Chlorophyll a (chl a) concentration in Onagawa Bay was measured for 2 size fractions using in vivo fluorometry.

In Onagawa Bay, sinking cysts were collected with a cylindrical sediment trap of $58 \mathrm{~cm}$ in height and $14 \mathrm{~cm}$ in inner diameter. The basic configuration of the trap is given by Sasaki \& Nishizawa (1981). The trap was deployed at $12 \mathrm{~m}$ depth intermittently, typically for 3 to $7 \mathrm{~d} \mathrm{mo}^{-1}$ from July 1993 to July 1994. Although a similar cylindrical trap of $45 \mathrm{~cm}$ in height and $12.5 \mathrm{~cm}$ in inner diameter was employed in Masan Bay, the mode of the sampling was not the same: the trap was deployed at $5 \mathrm{~m}$ depth continuously. It was retrieved and redeployed at 5 to $20 \mathrm{~d}$ intervals from October

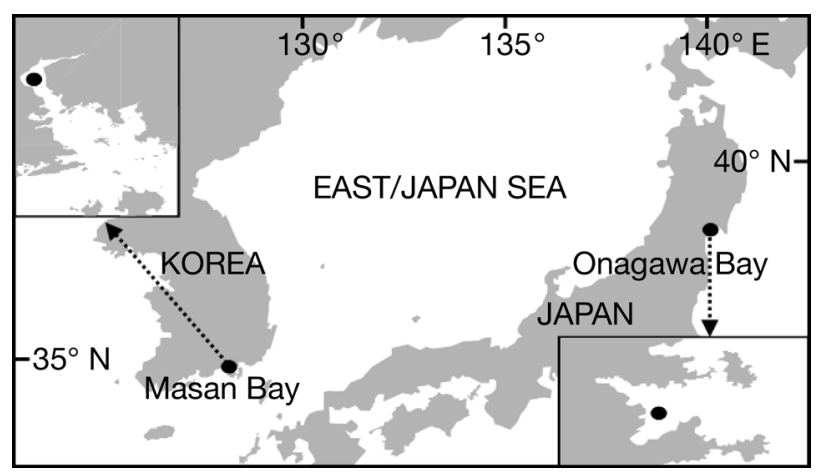

Fig. 1. Sampling stations in Onagawa Bay, Japan, and Masan Bay, Korea
2005 to November 2006, except December 2005 to January 2006 when the trap was lost in a storm. The trap in Onagawa Bay was pre-filled with dense artificial seawater $(\sim 40 \%)$ without preservatives from 23 July to December 1993 and with additional $4 \%$ neutralized formalin from 1 December 1993 to 13 July 1994. The trap in Masan Bay was deployed without being pre-filled to harvest live cysts.

After retrieval of the traps, supernatant water was gently removed, trapped particles were sonicated, and a 20 to $125 \mu \mathrm{m}$ fraction was sieved off with nylon mesh. The fraction was re-suspended in $10 \mathrm{ml}$ of filtered seawater and three $1.0 \mathrm{ml}$ aliquots were placed individually in Sedgwick-Rafter chambers. Observation, enumeration, and isolation of the cysts were conducted under an inverted microscope.

Cyst excystment. Intact cysts were sorted by using a capillary pipette under an inverted microscope (Kim \& Taniguchi 1995, 1997) and inoculated individually onto a tissue culture plate to incubate at $15^{\circ} \mathrm{C}$ under $14 \mu \mathrm{mol}$ photons $\mathrm{m}^{-2} \mathrm{~s}^{-1}$ with a 12:12 h light:dark cycle. Excystments were observed daily under an inverted microscope. The excysted vegetative cells were individually fixed with $5 \%$ Bouin's solution and observed after protargol staining. To observe well-developed cellular morphology, some vegetative cells were cultured in medium with $\mathrm{f} / 2$ iron-EDTA trace metal solution at $0.1 \mathrm{ml} \mathrm{l}^{-1}$, an appropriate volume of a mixture of the prymnesiophyte Isochrisis galbana, and natural small cells $(<10 \mu \mathrm{m})$ as food. They were placed under ca. $250 \mu \mathrm{mol}$ photons $\mathrm{m}^{-2}$ $\mathrm{s}^{-1}$ with a $12: 12 \mathrm{~h}$ light:dark cycle.

Identification of species was made under a light microscope based on the morphological characteristics of the anterior polykinetids (APk), ventral polykinetids (VPk), ventral kinety (VK), macronucleus (Mn), girdle, and the shape of the oral groove. For detailed examinations, the vegetative cells and cysts were fixed with $2 \%$ $\mathrm{OsO}_{4}(\mathrm{w} / \mathrm{v})$ in filtered seawater and with $5 \%$ buffered formalin, respectively. Fixed specimens were rinsed in distilled water, dehydrated in an alcohol series, and subjected to critical point drying and gold coating for scanning electron microscopy (SEM; JEOL 5600 LV).

\section{RESULTS}

\section{Cyst morphology}

Cysts of Strombidium capitatum were characterized by a distinctive spherical shape with a papula closed by a hyaline plug (Fig. 2). In some cases the base of the papula was surrounded by a short collar. The cyst wall enclosing the cytoplasm of dense granular structure was transparent and colorless but ornamented with numerous acutely tipped spines of ca. 1 to $3 \mu \mathrm{m}$ in 


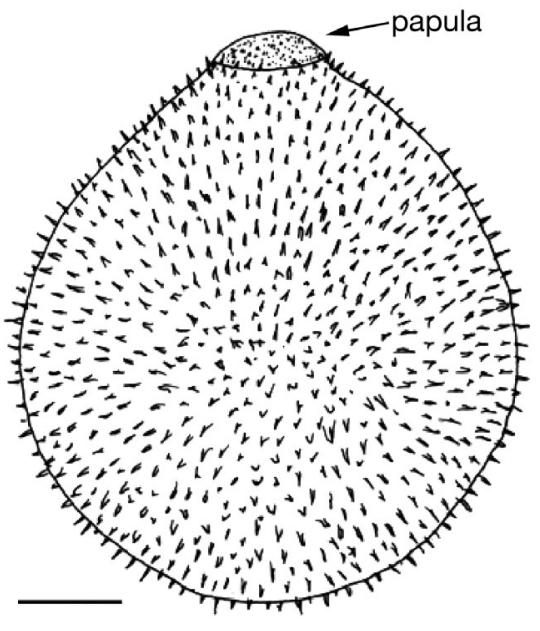

Fig. 2. Strombidium capitatum. Schematic drawing of a cyst. Scale bar $=10 \mu \mathrm{m}$ length. Under SEM, the spines were observed to be arranged at 1 to $2 \mu \mathrm{m}$ intervals. The papula surface was densely covered with very tiny granules (Fig. 3A-E). We did not observe autofluorescence in the live cysts. The size of 50 cysts from Onagawa Bay ranged from 60 to $62 \mu \mathrm{m}$ in length and from 50 to $55 \mu \mathrm{m}$ in diameter. The length and width of papula were 5 to 7 and 10 to $14 \mu \mathrm{m}$, respectively. The cysts ( $\mathrm{n}=50$ ) from Masan Bay were smaller in size, at 55 to $60 \mu \mathrm{m}$ in length and 45 to $50 \mu \mathrm{m}$ in diameter.

New excysted cells were very fragile and easily ruptured by fixatives. The ciliary structures of the anterior polykinetid zone (APZ), ventral polykinetid zone (VPZ), and ventral kinety (VK) were not clearly distinguished by protargol staining. However, further culturing after excystment made the ciliary structures clearer: APZ and VPZ were respectively composed of

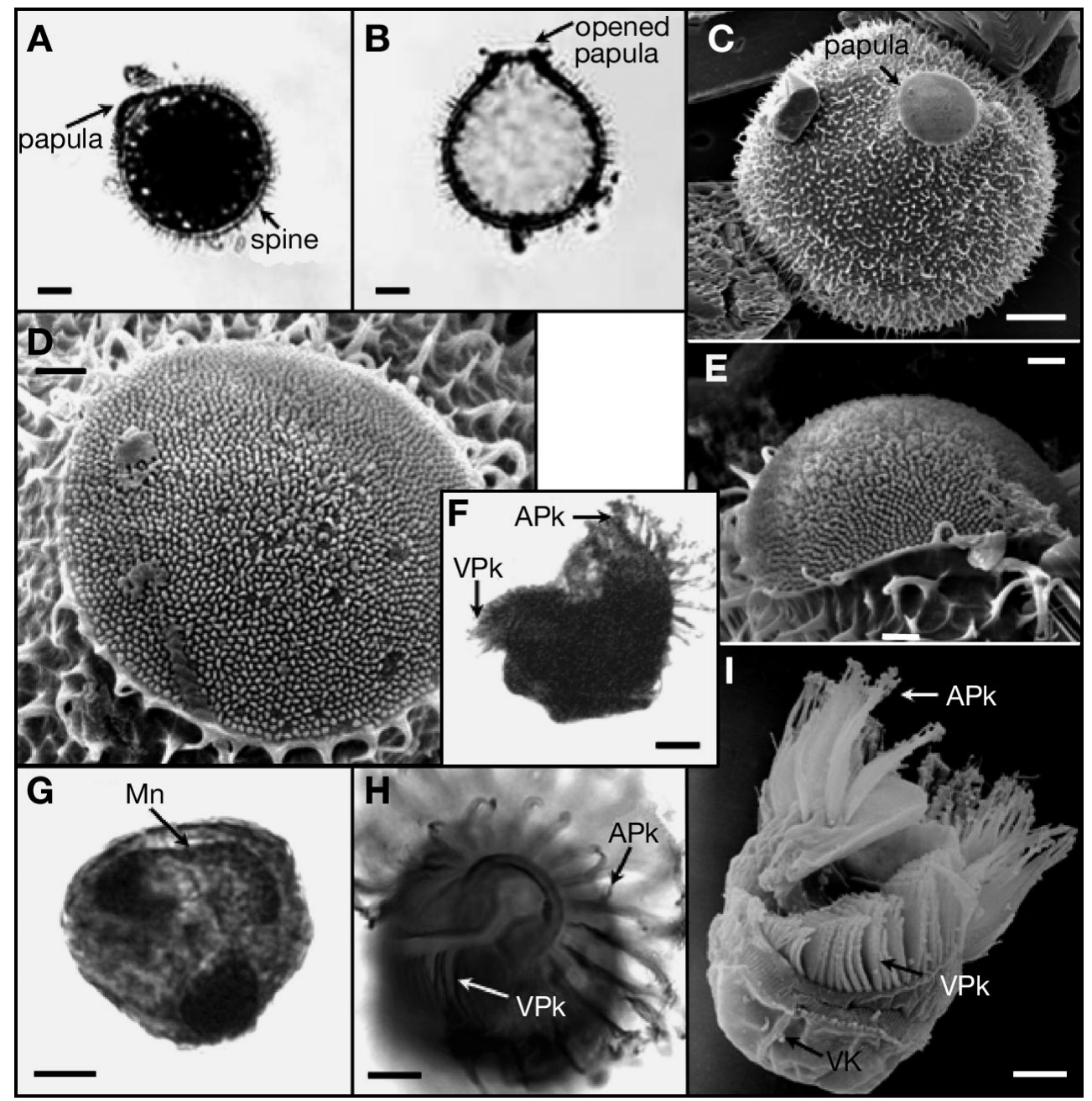

Fig. 3. Strombidium capitatum. (A) Cyst with a closed papula and spiny surface; (B) excysted cyst with an opened papula; (C) surface detail; (D) papula detail in upper view; and (E) in lateral view. Characteristic features of (F) an excysted cell and (G) macronucleus $(\mathrm{Mn})$ in detail. (H,I) Just-excysted and cultured cells showing well-developed anterior polykiditids (APk), ventral polykinetids (VPk), and ventral kinety (VK). (C), (D), (E), and (I) were microphotographed with scanning electron microscopy; (A), (B), (F), (G), and (H) with light microscopy. Scale bars $=10 \mu \mathrm{m}$, except (D) and (E) $(1 \mu \mathrm{m})$ 
14 to $15 \mathrm{APk}$ and 20 to $21 \mathrm{VPk}$, and VPZ formed a wide and deep ventral groove (Fig. 3F-I). It was observed that 1 macronucleus (Mn) appeared in the characteristic question mark shape, in both the just-excysted and additionally cultured cells. Based on these observations, the cysts were identified as belonging to Strombidium capitatum.

\section{Vegetative population and sinking cysts in Onagawa Bay}

Surface $(0.5 \mathrm{~m})$ temperature exhibited a typical seasonal pattern for temperate regions and rarely exceeded $20^{\circ} \mathrm{C}$ it ranged from a minimum of $7.2^{\circ} \mathrm{C}$ in March 1994 to a maximum of $20.2^{\circ} \mathrm{C}$ in September 1993. Salinity showed a reverse pattern to the temperature, with the lowest at 28.6 psu in July 1993 and highest at 34.2 psu in April 1994. Chl $a<10 \mu \mathrm{m}$ formed 2 peaks over $15 \mu \mathrm{g} \mathrm{l}{ }^{-1}$ in September 1993 and June 1994 (Fig. 4A).

The vegetative population of Strombidium capitatum at the same depth attained a seasonal maximum of

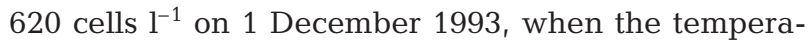
ture and salinity were ca. $15^{\circ} \mathrm{C}$ and 31.4 psu, respectively. The population persisted during the periods of low to moderate temperatures until June and then disappeared in the subsequent warm season until early September. It was interesting that the vegetative population was abundant (120 and 800 cells $\mathrm{l}^{-1}$, respectively) at 10 and $15 \mathrm{~m}$, while no cells could be found at $0.5 \mathrm{~m}$ in March 1994 (Fig. 4B).

Sedimentation at $12 \mathrm{~m}$ of the newly formed cysts was detected in the limited periods of March to April 1994 and September 1993. The former is the period when the vegetative population was distributed in deeper layers. The sedimentation reached a maximum of $1.4 \times$ $10^{5}$ cysts $\mathrm{m}^{-2} \mathrm{~d}^{-1}$ in March and de-creased rapidly until April. Sedimentation in September was minor (ca. 3000 cysts $\mathrm{m}^{-2} \mathrm{~d}^{-1}$ ), when the vegetative population also formed a minor peak. In contrast, no sedimentation was detected in November 1993 despite the secondary major peak in the vegetative population (Fig. 4C).

\section{Vegetative population and sinking cysts in Masan Bay}

Seasonal variations of temperature and salinity in the surface water in Masan Bay were also similar to other temperate regions. However, summer temperatures which were over $26^{\circ} \mathrm{C}$ in August were obviously higher, and annual range of salinity from 17.1 psu in July to 32.9 psu in February was generally lower than for Onagawa Bay (Fig. 5A). The lowest salinity was recorded in July when the rainfall is highest every year.
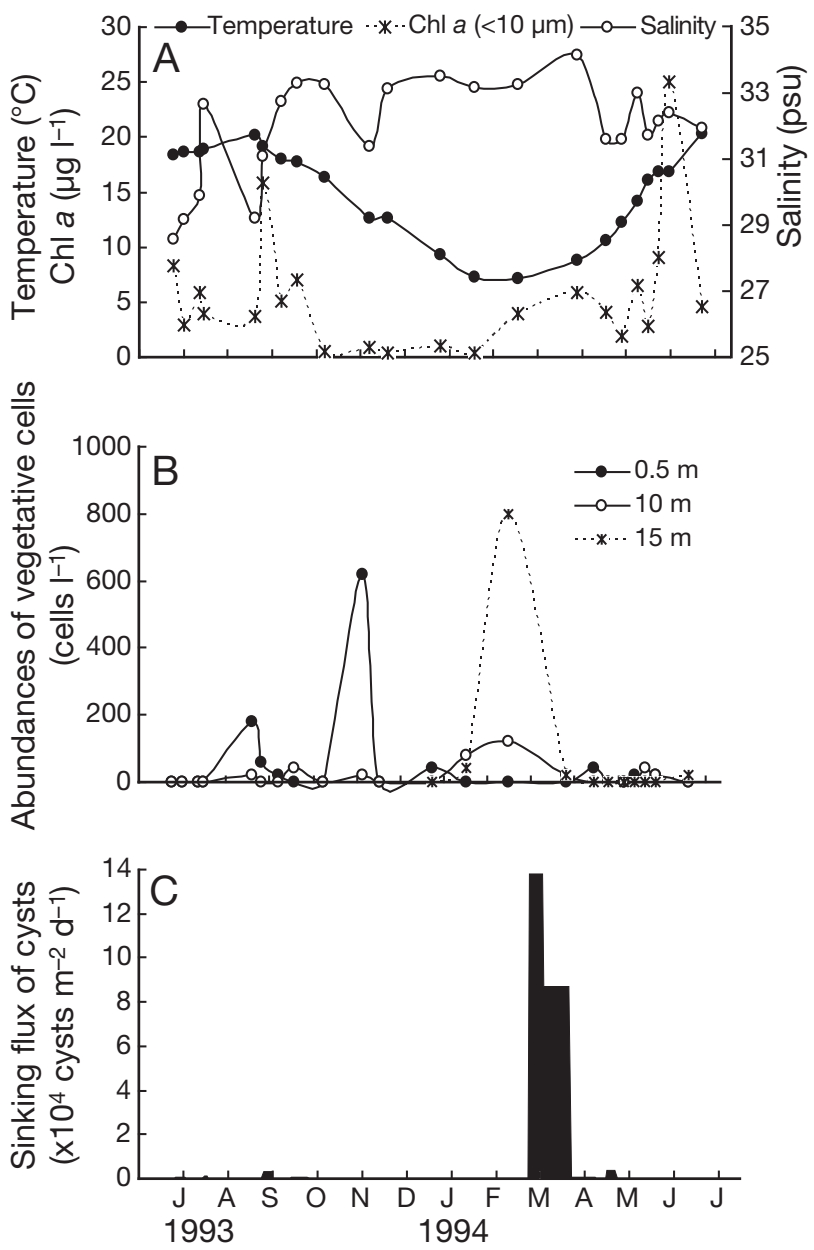

Fig. 4. Seasonal changes of (A) water temperature, salinity, and concentration of chlorophyll $a<10 \mu \mathrm{m}$ at $5 \mathrm{~m}$, (B) abundances of vegetative cells of Strombidium capitatum at 0.5, 10 and $15 \mathrm{~m}$, and (C) daily flux of sinking cysts entrapped at $12 \mathrm{~m}$ during the period from July 1993 to July 1994 at the station in Onagawa Bay

The abundance of the vegetative population of Strombidium capitatum in surface water was apparently higher than in Onagawa Bay and exhibited an acute seasonal pattern. Although they occurred from January to May and from October to November 2006 when temperatures were between 15 and $21^{\circ} \mathrm{C}$, a sharp peak appeared in April when the temperature was $15^{\circ} \mathrm{C}$. The maximum abundance reached $10^{4}$ cells $\mathrm{I}^{-1}$ in April, while the peaks in May and October were

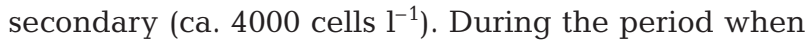
temperature was $>20^{\circ} \mathrm{C}$ from May to September, vegetative cells were not found in the surface (Fig. 5B).

Cyst sedimentation was more or less detected throughout the year except later July through early October, while December through early February was not sampled due to heavy winter storms. Mass sedimentation $>6000$ cysts $\mathrm{m}^{-2} \mathrm{~d}^{-1}$ was recorded in late 

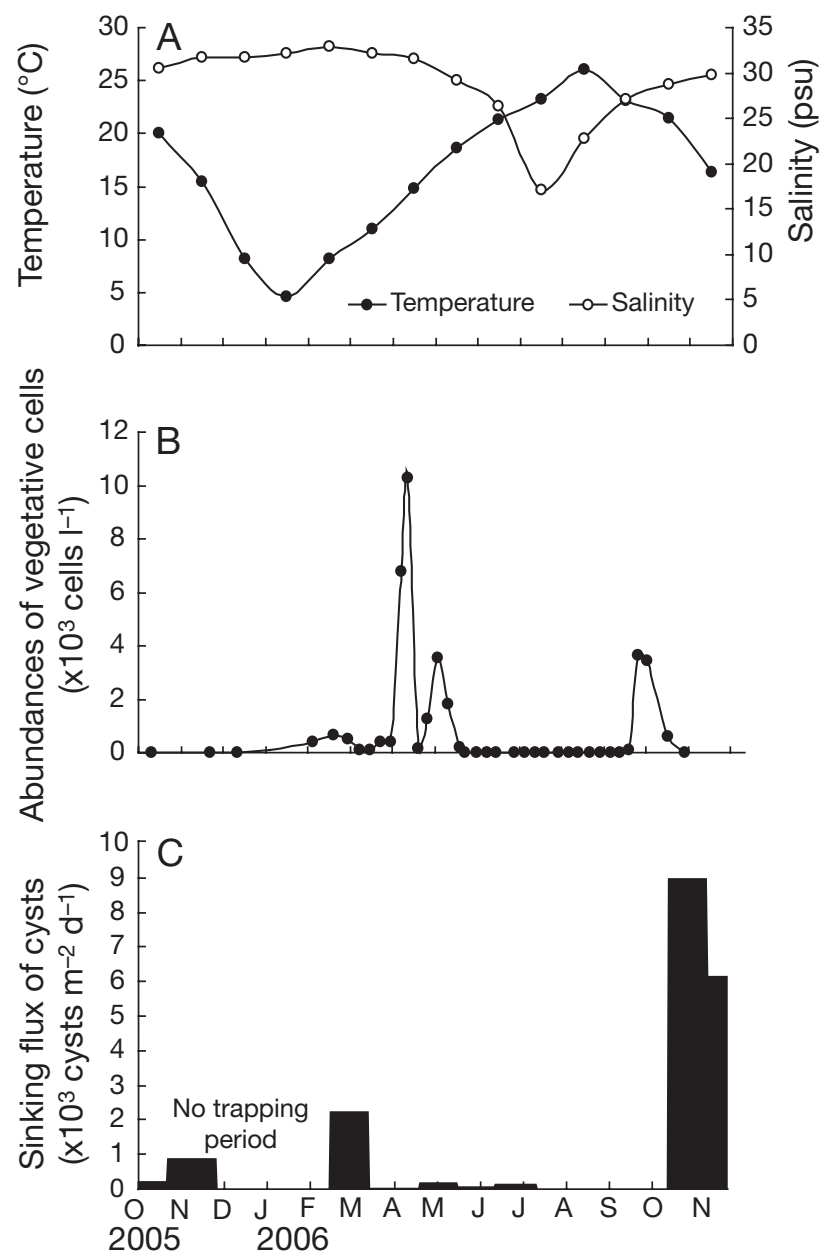

Fig. 5. Seasonal changes of (A) water temperature and salinity at the surface, (B) abundances of vegetative cells of Strombidium capitatum at $0.5 \mathrm{~m}$, and (C) daily flux of sinking cysts entrapped at $10 \mathrm{~m}$ during the period from October 2005 to November 2006 at the station in Masan Bay

October to November 2006, when the vegetative population formed a minor peak. In contrast, when the vegetative population was at a maximum, the sedimentation was low (ca. 200 cysts m$^{-2} \mathrm{~d}^{-1}$ ) (Fig. 5C).

\section{DISCUSSION}

\section{Cyst morphology}

The cysts of Strombidium capitatum are short ellipses of $50 \times 63 \mu \mathrm{m}$. Its surface is covered with numerous short and straight spines of ca. $2 \mu \mathrm{m}$ long with a sharp point, which are evenly spaced with 1 to $1.5 \mu \mathrm{m}$ intervals. The morphologically similar cysts of $S$. crassulum are covered with curled spines with a somewhat blunt tip. The surface of the hyaline plugs of papulae is also different between these 2 species: a granular structure is observed in $S$. capitatum, while $S$. crassulum is smooth without such a structure (Reid 1987). While the cysts of the freshwater Pelagostrombidium fallax are also covered with spines, their spines are robust at 3 to $4 \mu \mathrm{m}$ long, $0.2 \mu \mathrm{m}$ wide, and anchored to the surface with fine fibers (Müller 1996). These spiny decorations are said to confer several advantages to the cysts and are observed in many resting forms of planktonic organisms (Belmonte et al. 1997). As in those known organisms, the spiny structure in $S$. capitatum likely confers suspending capability and resistance against predation/digestion to the cysts. These functions may be important in oligotrich ciliates, for their cyst walls are composed of fragile chemical components such as chitin and proteins.

A difference in cell size of the same species among localities is reported for Strombidium inclinatum between the Ligurian Sea, Italy, and Kingston Harbour, Jamaica (Montagnes et al. 1990, Lynn \& Gilron 1993, Modeo et al. 2003). A similar difference in vegetative cells and cysts between Korea and Japan was detected for $S$. capitatum. The vegetative cells of $S$. capitatum are slightly larger in Onagawa Bay, Japan (52.5 $\mu \mathrm{m}$ long, $45.7 \mu \mathrm{m}$ wide, $\mathrm{n}=50$ ), than in Masan Bay, Korea (50.5 $\mu \mathrm{m}$ long, $43.7 \mu \mathrm{m}$ wide, $\mathrm{n}=50$ ). MannWhitney $U$-test revealed significant differences in their length $(p<0.001)$ and width $(p=0.008)$. The length and width of the cysts are also significantly different between the 2 bays $(p<0.001)$. Warmer conditions usually cause a decrease in cell size (Atkinson 1994). In another oligotrich known as a boreal species, Cyrtostrombidium boreale in Onagawa Bay, cell size diminishes with increasing temperature (Kim et al. 2002). A higher average summer temperature in Masan Bay than in Onagawa Bay might suggest that temperature also leads to the size difference observed in $S$. capitatum between the 2 bays. However, since $S$. capitatum tended to be most abundant during periods when water temperature was ca. 15 to $20^{\circ} \mathrm{C}$ in both Masan Bay and Onagawa Bay, it seems unlikely that the size difference was a thermal effect. Müller et al. (2002) reported that the cysts of the freshwater Pelagostrombidium species are largest when the putative prey is abundant. If the nutritional state of vegetative cells also determines cyst size in $S$. capitatum, our finding suggests that the feeding condition is better in Onagawa Bay than in Masan Bay. This might be the case, because the former bay is under the direct influence of the productive subarctic Oyashio water and the latter bay under the influence of the less productive East/Japan Sea water originating from subtropical Kuroshio water. This suggests that cyst size can be an indication of the feeding conditions of the vegetative populations in oligotrich ciliates. 


\section{Vegetative population}

Strombidium capitatum has been described as a eurythermal species, occurring at temperatures of 5 to $24^{\circ} \mathrm{C}$ and a salinity of 31 to $32 \mathrm{psu}$ in Great Harbor, Woods Hole, USA (Montagnes et al. 1988). This species was also found in the inner zone of Bahia Blanca Estuary, Argentina, where salinity was 29 to 30 psu and temperature 12 to $21^{\circ} \mathrm{C}$ (Pettigrosso 2003). In the present study, this species was observed to generally be more abundant in Masan Bay than in Onagawa Bay. While the water in the former is warmer and less saline, this species flourished in April 2006, when salinity was ca. $28 \mathrm{psu}$ and temperature was ca. $15^{\circ} \mathrm{C}$. In the colder and more saline Onagawa Bay, it peaked in early December when salinity and temperature were ca. $31 \mathrm{psu}$ and $13^{\circ} \mathrm{C}$, respectively. It is noteworthy that the peaks on 16 September and 1 December 1993 in Onagawa Bay were coincident with temporal decreases in salinity (Fig. 4A,B). This seems to indicate that the vegetative population of $S$. capitatum prefers relatively low salinity (28 to $31 \mathrm{psu}$ ) and moderate temperature $\left(13\right.$ to $\left.15^{\circ} \mathrm{C}\right)$. This agrees with the finding of Crawford \& Stoecker (1996) that the optimal temperature for laboratory cultures of this species is $15^{\circ} \mathrm{C}$.

Planktonic ciliate distribution generally shows a close association with the distribution of chl a. However, we could not detect any significant relationship in abundance between Strombidium capitatum and chl $a<10 \mu \mathrm{m}$ in Onagawa Bay. The concentration of chl a (not size-fractionated) was lowest when the $S$. capitatum population was at its peak in Masan Bay (KORDI 2006). This indicates that the dependence of this species on prey abundance is not strong because of its mixotrophic nutrition (Montagnes 1996).

Considering the very high growth rate of Strombidium capitatum (max. $1.07 \mathrm{~d}^{-1}$ ) measured by Montagnes (1996), this species can produce a large population within a limited period of a few weeks, and similarly the crash of the population may occur in a short period. The present sampling frequency was once a month in Onagawa Bay, with longer intervals than in Masan Bay, where weekly sampling was conducted. This is likely the reason why peaks in Masan Bay were sharp but broader in Onagawa Bay. In the latter bay, some peaks might be missed. To further explore the population dynamics in $S$. capitatum on a regional difference, more frequent sampling is necessary.

\section{Cyst sedimentation}

It is generally known that sediment traps of different configurations collect sinking particles at different efficiencies. However, despite the uncertainty in quantity, the sediment traps are the most convenient tool to obtain qualitative information such as timing of the cyst formation and the relative magnitude of the formation (Matsuoka et al. 1989).

Massive sedimentation of Strombidium capitatum cysts was detected during 2 to 28 March 1994 in Onagawa Bay, when temperature decreased to a minimum. On these days, vegetative cells were absent from the upper water column but densely distributed in the underlying layers (10 and $15 \mathrm{~m})$. A minor sedimentation event $\left(\sim 3000\right.$ cysts $\left.\mathrm{m}^{-2} \mathrm{~d}^{-1}\right)$ was observed in September 1993, when a minor peak in the vegetative population was formed at the surface. During the population peak in the vegetative population in early November 1993, no cyst sedimentation was observed. This indicates different ways of cyst formation between minor and mass sedimentation periods. The latter might be caused by a synchronized encystment of the whole population of $S$. capitatum. An analogous phenomenon was recorded in 2 freshwater lakes, i.e. the peak sedimentation of the cysts in autumn occurred almost simultaneously in both lakes, while there was minor sedimentation in spring, with peaks occurring at different times (Müller \& Wünsch 1999, Müller et al. 2002). The abundance peaks in autumn did not correspond to the peak of vegetative cells.

In contrast, the concurrence of mass encystment and vegetative reproduction was observed for Limnostrombidium viride in Lake Constance (Müller \& Wünsch 1999) and for Strombidium conicum and Cyrtostrombidium boreale in Onagawa Bay (Kim 1995, Kim et al. 2002). Therefore, encystment is likely regulated by the species-specific processes.

Cyst sedimentation of Strombidium capitatum was basically the same in Masan Bay and Onagawa Bay. It occurred twice a year-in autumn (September to November) and in spring (February to May) - while its magnitude and seasonal variability were different between the 2 bays. Among over 10 types of cysts possessing papular structures collected by the sediment traps in Masan Bay, the most abundant was for S. capitatum. Dominance of the same species was also often highest in Onagawa Bay, reaching $1.5 \times 10^{6}$ cysts $\mathrm{m}^{-2} \mathrm{yr}^{-1}$ in flux and composed $74 \%$ of the total cyst sedimentation (Kim 1995). Thus, S. capitatum is the most successful species among the planktonic oligotrichs in the coastal waters around Korea and Japan.

The difference in magnitude and time of the seasonal peak in sedimentation of Strombidium capitatum cysts between the 2 bays, as well as the disparity in their size, may reflect a difference in the environmental conditions between the bays. As mentioned in 'Discussion: Cyst morphology' above, the 2 bays are under the influence of different oceanic currents, and therefore the Onagawa Bay water is colder with less 
seasonal fluctuations than Masan Bay. Furthermore, the salinity of Onagawa Bay is higher, but with a lower seasonal fluctuation than Masan Bay. Such physical differences in the environmental conditions could directly affect cyst formation in $S$. capitatum, but they also likely influence other biological processes in the 2 bays, including species composition of potential prey, which has been implicated in differences in cysts for other ciliates.

Acknowledgements. We sincerely thank W. D. Yoon for providing water samples collected from Masan Bay and S. W. Jeong for assistance with SEM observations. We also thank 3 anonymous reviewers for their comments on an earlier draft of the manuscript. Prof. P. J. Harrison, Hong Kong University of Science and Technology, assisted us in revising the manuscript. This work was partially supported by the Korea Science and Engineering Foundation (KOSEF) grant funded by the Korea Government (MOST) (No. R01-2006-000-10466-0).

\section{LITERATURE CITED}

Atkinson D (1994) Temperature and organism size - a biological law for ectotherms? Adv Ecol Res 25:1-58

Belmonte G, Miglietta A, Rubino F, Boero F (1997) Morphological convergence of resting stages of planktonic organisms: a review. Hydrobiologia 355:159-165

Crawford DW, Stoecker DK (1996) Carbon content, dark respiration and mortality of the mixotrophic planktonic ciliate Strombidium capitatum. Mar Biol 126:415-422

Foissner W (2005) The unusual, lepidosome-coated resting cyst of Meseres corlissi (Ciliophora: Oligotrichea): transmission electron microscopy and phylogeny. Acta Protozool 44:217-230

Foissner W, Müller H, Weisse T (2005) The unusual, lepidosome-coated resting cyst of Meseres corlissi (Ciliophora: Oligotrichea): light and scanning electron microscopy, cytochemistry. Acta Protozool 44:202-215

Foissner W, Pichler M, Al-Rasheid K, Weisse T (2006) The unusual, lepidosome-coated resting cyst of Meseres corlissi (Ciliophora: Oligotrichea): encystment and genesis and release of the lepidosomes. Acta Protozool 45:323-338

Kim YO (1995) Life cycle strategies of choreotrich ciliate plankton in Onagawa Bay. PhD thesis, Graduate School of Agriculture, Tohoku University, Sendai

Kim YO, Taniguchi A (1995) Excystment of the oligotrich ciliate Strombidium conicum. Aquat Microb Ecol 9:149-156

Kim YO, Taniguchi A (1997) Seasonal variation of excystment pattern of the planktonic oligotrich ciliate Strombidium conicum. Mar Biol 128:207-212

Kim YO, Suzuki T, Taniguchi A (2002) A new species in the genus Cyrtostrombidium (Ciliophora, Oligotrichia, Oligotrichida): its morphology, seasonal cycle and resting stage. J Eukaryot Microbiol 49:338-343

Kim YO, Chae J, Hong JS, Jang PG (2007) Comparing the distribution of ciliate plankton in inner and outer areas of a harbor divided by an artificial breakwater. Mar Environ Res 64:38-53

Editorial responsibility: Robert Sanders,

Philadelphia, Pennsylvania, USA
KORDI (2006) Environmental risk assessment of the special management areas in the south sea of Korea. Technical Report, Korea Ocean Research \& Development Institute, Ansan, p 452-457

Laval-Peuto M, Rassoulzadegan F (1988) Autofluorescence of marine planktonic Oligotrichina and other ciliates. Hydrobiologia 159:99-110

Lynn DH, Gilron GL (1993) Strombidiid ciliates from coastal waters near Kingston Harbour, Jamaica (Ciliophora, Oligotrichia, Strombidiidae). J Mar Biol Assoc UK 73: 47-65

Matsuoka K, Fukuyo Y, Anderson DM (1989) Methods for modern dinoflagellate cyst studies. In: Okaichi T, Anderson DM, Nemoto T (eds) Red tides: biology, environmental science, and toxicology. Elsevier, New York, p 461-479

Modeo L, Petroni G, Rosati G, Montagnes DJS (2003) A multidisciplinary approach to describe protests: redescriptions of Novistrombidium testaceum Anigstein 1914 and Strombidium inclinatum Montagnes, Taylor, and Lynn 1990 (Ciliophora, Oligotrichia). J Eukaryot Microbiol 50: 175-189

> Montagnes DJS (1996) Growth responses of planktonic ciliates in the genera Strobilidium and Strombidium. Mar Ecol Prog Ser 130:241-254

Montagnes DJS, Lynn DH (1987) A quantitative protargol stain (QPS) for ciliates: method description and test of its quantitative nature. Mar Microb Food Webs 2:83-93

Montagnes DJS, Lynn DH, Stoecker DK, Small EB (1988) Taxonomic descriptions of one new species and redescription of four species in the family Strombidiidae (Ciliophora, Oligotrichida). J Protozool 35:189-197

Montagnes DJS, Taylor FJR, Lynn DH (1990) Strombidium inclinatum n. sp. and a reassessment of Strombidium sulcatum Claparède and Lachmann (Ciliophora). J Protozool 37: 318-323

Müller H (1996) Encystment of the freshwater ciliate Pelagostrombidium fallax (Ciliophora, Oligotrichida) in laboratory culture. Aquat Microb Ecol 11:289-296

Müller H (2007) Live observation of excystment in the spirotrich ciliate Meseres corlissi. Eur J Protistol 43: 95-100

> Müller H, Wünsch C (1999) Seasonal dynamics of cyst formation of pelagic strombidiid ciliates in a deep prealpine lake. Aquat Microb Ecol 17:37-47

Müller H, Stadler P, Weisse T (2002) Seasonal dynamics of cyst formation of strombidiid ciliates in alpine Lake Mondsee, Austria. Aquat Microb Ecol 29:181-188

Pettigrosso RE (2003) Planktonic ciliates Choreotrichida and Strombidiida from the inner zone of Bahía Blanca Estuary, Argentina. Iheringia Sér Zool Porto Alegre 93: $117-126$

Rassoulzadegan F (1977) Évolution annuelle des ciliés péagiques en Méditerranée nord-occidentale ciliés oligotriches (non tintinnides). Ann Inst Oceanogr Paris (Nouv Ser) 53:125-143

> Reid PC (1987) Mass encystment of a planktonic oligotrich ciliate. Mar Biol 95:221-230

- Sasaki H, Nishizawa S (1981) Vertical flux profiles of particulate material in the sea off Sanriku. Mar Ecol Prog Ser 6:191-201

Stoecker DK, Silver MW, Michaels AE, Davis LH (1988/1989) Enslavement of algal chloroplasts by four Strombidium spp. (Ciliophora, Oligotrichida). Mar Microb Food Webs 3: 79-100 